\title{
Moderating Effect of Financial Strength on the Relationship Between Board Characteristics and Environmental Sustainability Disclosures
}

\author{
Paul Gichuki King'ori \\ Department of Finance and Accounting, University of Kabianga, Kenya \\ Isaac Kiprotich Naibei \\ Department of Finance and Accounting, University of Kabianga, Kenya \\ Hellen Wothaya Sang \\ Department of Finance and Accounting, University of Kabianga, Kenya \\ Andrew Kibet Kipkosgei \\ Department of Curriculum Instruction and Education Media, University of Kabianga, Kenya
}

\begin{abstract}
The study examines the moderating effect of financial strength on the relationship between board characteristics (board independence and qualification) and ecological sustainability disclosures on firms listed at the Nairobi Securities Exchange. The study period was (5) years (from 2013 to 2017). It employed a correlational survey research design covering the period of five (5) years (2013 - 2017). The target population was sixty-five (65) firms listed at the NSE, with a sample size of 56 firms. Data was utilised from firms' annual reports, stand-alone reports, and website. Pearson's correlation, Ordinary Least Square regression model and Environmental Disclosure Index were used in analysis. The results showed that financial strength strengthen the relationship between environmental sustainability disclosure and board independence $(\beta=.23, \rho<.01)$. A negative and significant moderating effect of financial strength on the relationship between board meetings and environmental sustainability disclosure $(\beta=$ $-.16, \rho<.05)$ was found. For the board qualification, positive and insignificant effect of financial strength was observed $(\beta=.13, \rho>.05)$. The study concluded that financial strength has significant moderating effect on the relationship between board characteristics and environmental sustainability disclosure. It recommends enactment of policies addressing corporate environmental reporting by firms as a result of different asset base. Future studies need to focus on; specific dimensions such as directors' experience, age, and nationality, use of more measures of firms financial strength such as risk analysis, cross listing and profitability.
\end{abstract}

Keywords: Corporate characteristics, environmental sustainability disclosures, financial strength, listed firms, trinity theory.

DOI: $10.7176 /$ RJFA/10-18-13

Publication date:September $30^{\text {th }} 2019$

\subsection{Introduction}

For a long time, most of the firms have majorly been concerned about profit and wealth maximization, and sluggishly engaging on some social responsibility activities such as philanthropy. More so, little attention has been directed towards the management of environmental-related issues through disclosure. Globally, there has been witnessed growing pressure as a result of unprecedented climate change as well as environmental degradation health related problems, all of them attributed to firms' activites, for firm's responsibility and adherence towards environmental policies and guidelines. On this note, environmental disclosures has started to gain momentum among several firms more especially in developed economies and few emerging economies (Aburaya, 2012; Kathyayini, Carol and Laurence, 2012, Borunda, 2019; Climate Central, 2019).

Companies that are trading their securities at the Nairobi securities exchange are oversighted by the Capital Markets Authority (CMA) of Kenya, through Capital Markets Authority Act, 2002 (cap. 485a) of the laws of Kenya (ICPAK, 2017). With the increased rate of ecological degradation witnessed in recent years (Ofoegbu and Megbuluba, 2016; Omofonmwan and Osadah, 2008), more attention needs to be directed towards environmental sustainability disclosures by corporate bodies. The decision on which firm, when, how, what and to what extent to disclose the ecological matters rest upon an entity's corporate governance mechanism (Agyei-Mensah, 2016). However, address towards ecological degradation through firms' operations remains patchy. Oludayo (2012) attributes this towards failure by the regulatory authorities in designing proper practices which provide effective as well as efficient enforced and complied with global and country ecological laws. Recently, several firms listed at the NSE have been involved in cases of corporate scandals, thus bringing into question the need for corporate governance. Most of the studies on corporate ecological sustainability reporting have directed much attention on 
firm attributes (such as profitability, asset base, industry affiliation, market capitalization, debt level as well as risk analysis) at the expense of corporate governance mechanisms (Chepkwony, 2015; Kipkorir, 2015; Musyoka, 2017; Mutiva, 2015; Ngatia, 2014; Barako, Hancock and Izan, 2006). These mechanisms are paramount in addressing corporate ecological failures (Aburaya, 2012). Previous studies have not been able to look into the impact of corporate strength on corporate ecological disclosures, more so with the disparities in disclosure experienced across various firms.

The study therefore intended to fill this gap by evaluating the moderating effect of financial strength on the relationship between firms' board characteristics and ecological sustainability disclosures. Board characteristics were measured by board independence and board, while ecological sustainability disclosures were measured through the Global Reporting Guidelines (GRI). For the financial strength, it was determined by the natural logarithm of the total asset base.

\subsection{Literature Review and Hypothesis \\ 1.2.1 Board characteristics}

Board characteristics in form of board independence, board qualifications and board meetings, constitutes majorly towards corporate governance mechanisms. The directors board is vital towards administration of all entity information disclosure in annual reports. It greatly contributes towards firm governance structures that may be directly associated with an entity environmental phenomenon (Bhagat and Bolton, 2008). Therefore, board characteristics are assumed to have great effect towards ecological sustainability reporting decisions.

\subsubsection{Financial Strength}

The financial strength, in form of firm size has varied effects on the business such as patronage, goodwill, customer loyalty and responsiveness towards its stakeholders. Previous research have indicated the connection between firm size with corporate social responsibility (Anazonwu, Egbunike, and Gunardi, 2018; Habbash, 2016; Khan, 2010), as bigger companies tend to be more salient, therefore, tend to attract more attention from the stakeholders, who may compel them to appear good (Hyun, Yang, Jung, and Hong, 2016).Small firms as asserted by Obigbemi, Iyoha and Ojeka (2015) in most cases do not publish their end year reports and when they do so, is as a result of the statutory requirements.

On the other hand, large firms due to their expansive shareholders base as well as their diverse background, they are compelled to disclose all the requisite information in order to not only retain but also enhance its reputation, investment and attract other prospective investors to the firm. Past studies have indicated that big firms even though they are endowed with more resources as well as earning higher profits (Swastika, 2013), normally adopt discretionary reporting frequently as compared to the smaller firms (Barako and Brown, 2006; Khodadadi, Khazami, and Aflatooni, 2010). The firm financial strength was preferred due to its significant influence on the quantity of overall ecological disclosure of several firms (Odoemelam and Okafor, 2018). This supports the study's application of the financial strength as the moderating variable.

\subsubsection{Environmental Sustainability Disclosure}

Simpson (2013) asserted the word disclosure to entail "sharing, releasing, and communicating some useful" and relevant information. Traditionally, disclosure in accounting had been linked to conventional financial reporting, which in recent years has been broadened to incorporate among others value disclosure, sustainability disclosure (Mahadeo, Oogarah-Hanuman, and Soobaroyen, 2011; Farneti and Guthrie, 2009; Williams, 2008). Natural sustainability disclosure has two key implications: (i) creating reports yet likewise (ii) disclosure of data (Niemann and Hoppe, 2017).

Sustainability disclosure detailing improvements have taken distinctive structures, one of them being triple bottom line (TBL) disclosure concept as shown in figure 1, where the three measurements are social, monetary and natural, or individuals, planet and benefit (Elkington, 1997). For corporate governance effectiveness, the concept has been cited as the most appropriate due to its holistic nature of value creation over the short, medium and long term (McFie, 2018). The concept has been attributed from the accounting profession and accounting bodies growing support, which results in likely changes within organization and management as well as the take with which 'institutions might communicate with the community and stakeholders in the provision of its services and operations'(Barrett, 2004). In the meantime, worldwide institutions supporting sustainability disclosures were established. One of them is the Global Reporting Initiative (GRI) that has built up a willful sustainability disclosure system. The study used the GRI (2011) towards developing the ecological reporting checklist comprising several items as applied in past studies (Odoemelam and Ofoegbu, 2018; Odoemelam, Ofoegbu and Okafor, 2018) 


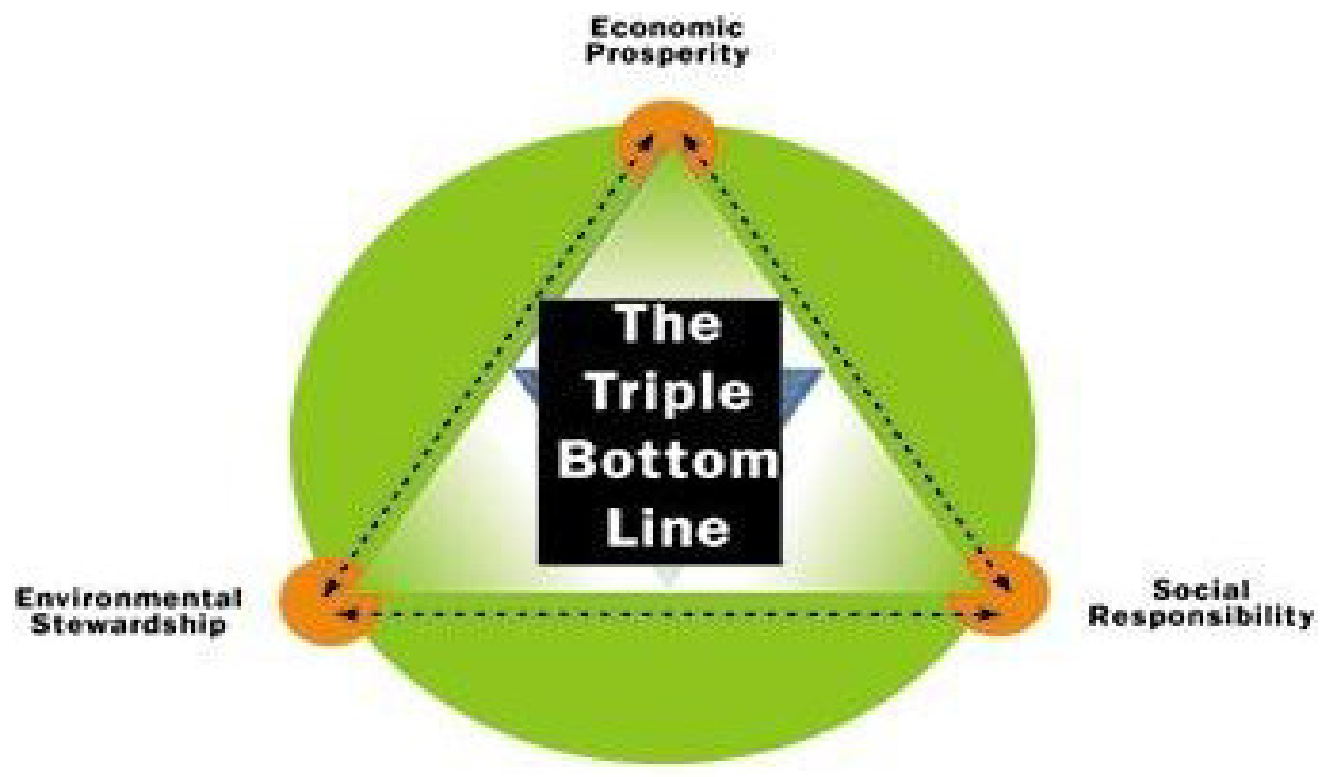

Figure 1: The Triple Bottom Line (TPL)

Source: adopted from Elkington (1997)

Environmental reporting can in simpler way be termed as the disclosures involving effect that an organizational process or operation might have on the natural ecology (Campbell, Craven and Shrives, 2004). In a comprehensive direction, it can be defined as the group of information items relating to an entity's past, present as well as future ecological administration activities together with performance. Corporate ecological reporting as well constitutes information concerning the historical, present and expected monetary implications emanating from a firm's ecological administration decisions or actions.

\subsubsection{Empirical Literature}

Qingliang and Luo (2016) results indicated significant relationship between firm size and environmental transparency. Ettredge (2011) observed that size was not highly associated with the disclosure compliance at $p=.192$. However, large firms characterised with the value of equity more than $\$ 75$ million were marginally significant at $\mathrm{p}=.093$. The study nevertheless due to its inferences with regard to lack of explanatory power of size in the presence of variables having corporate governance quality could not be applied to other disclosure settings which do not exhibit similar features. In Australia, Karim and Rutledge (2004) found a pessimist association between the magnitude of public as well as private organizations and the extent of environmental disclosures $(p=.719)$ with an adjusted $R^{2}$ of .325 . A stakeholder and legitimacy theory guided the study. In Nigeria, a study by Dibia and Onwuchekwa (2015) indicated a negative moderating effect of firm magnitude on the association between corporate characteristics and environmental disclosures [ $(\operatorname{logit}$ model, $\beta 1=-.141, \mathrm{p}=.00)$ (probit model, $\beta 1=-.088, p=.00)]$. Stakeholders' theory guided the study. Consistent with the study findings were Prado-Lorenzo (2009), Reverte (2009), while Echave and Bhati (2010) who found no significant moderating effects of firm size. Thus, the study hypothesizes, in null form, that:

$H_{01}$ : There is no significant moderating effect on the relationship between financial strength and environmental sustainability disclosure

Previous studies have applied various theories towards discussing the impact and relationship between CG and ESD (Mahmood and Orazalin, 2017). The study was guided by the trinity theory (legitimacy theory, stakeholder theory, and agency theory).

\subsubsection{Legitimacy theory}

Legitimacy theory is one of the dominating theories in the area of societal disclosure studies (Bhattacharyya, 2014; Chen and Robert, 2010). The theory can be construed to entail a sense of approval that may be realized through harmony construction between social values as well as firms' behaviours (Lodhia, 2010). The theory insists that an entity need to uphold accountability for its actions (Greiling and Grüb, 2014).

The theory has extensively been applied by the firms and their managers, mainly due to the public prominence as well as those companies with poor environmental track record trying to gain legitimacy through disclosing sustainability information in their financial reports (Cho and Patten, 2007; Deegan, 2002). This in the process influences as well as captures environmental agenda in the financial reports (Larrinaga-Gonzalez and Bebbington, 2001; Owen, Swift, Humphrey and Bowerman, 2000; O’Dwyer, 2003). Also, its wide use in the corporate sector 
is alleged to serve the interest of all firms' stakeholders. This is due to the fact that corporate sector entities have a "contracts legitimizing their existence and actions" (Cormier and Gordon, 2001).

\subsubsection{Stakeholder theory}

Stakeholder theory observes that corporate governance must incorporate an all-inclusive approach that appreciates as well as ensures the members' and stakeholders' rights are taken care of (Bokpin, Isshaq and Nyarko, 2015). The theory is an extension of the agency perspective as the role of the administrative organ is enhanced from ensuring the safeness of only the shareholder's interest in protecting all stakeholders' interests. Thus the narrow perspective of agency through focus of shareholders only has been significantly changed, with the theory taking into account that is linked to several social, ecological and ethical considerations. It, therefore, support improvements on corporate reporting policies, implementation of CSR practices as well as the establishment of risk administration policies towards managing the conflicting interest of different stakeholders. With the increased awareness on the need to protect the ever degrading environment, this has resulted to pressure by the stakeholders towards firm's being compliant more especially on their activities. A firm's goals and objectives can be realised by ensuring a balance towards the 'conflicting interests' of all interested stakeholders (Mahmood and Orazalin, 2017).

\subsubsection{Agency theory}

Agency theory is alluded by Zahra and Peace II (1989) as the most appreciated as well as prominent perspective which has guided studies on corporate boards. The theory suggests that within the framework of CG mechanisms, the managers have a high likelihood of emphasizing on corporate social and ecological issues than stockholders since they have no salvage claim on an entity's generations. The assumptions underlying corporate governance and ecological reporting are agency theory (Jensen and Meckling, 1976) that creates the framework for the connection between the variables (Odoemelam and Okafor, 2018; Kabir and Thai, 2017; Allegrini and Greco, 2013; Ienciu, Popa and Ienciu, 2012).

\subsection{RESEARCH METHODOLOGY}

Pragmatic philosophical approach was used, premised on the assumption that research commences with a gap, and it is geared towards contributing hands on solutions which may inform future operations (Saunders, 2016). A correlational survey design on a panel data over 5 years (2013-2017) period was used. Correlational researches display the association between variables through for instance correlations and cross-tabulation techniques, (Chepkwony, 2017) and thereafter deriving a regression model meant to predict about the population. This design is appropriate in ascertaining the way and magnitude of association between the variables (Onuorah, Egbunike and Gunardi, 2018).

The study population was all 65 listed firms at the Nairobi Securities Exchange (NSE) for the financial period 2017/2018 (Nairobi Securities Exchange, 2013; Cheruiyot, 2017). A sample size of 56 firms was purposively determined based on firms' disclosure of environmental information. Secondary data was used such as firms' annual report, stand-alone report, as well as company website. Inferential statistical test techniques such as JarqueBera tests, Shapiro Wilk tests were applied towards test of data normality. Pearson correlation was as well applied in testing collinearity. Hausman test was used in determining the regression model applied.

\subsection{RESULTS AND DISCUSSIONS}

\subsubsection{Findings}

For the Jarque-Bera Test as indicated in the Table 1, the chi-square is 0.5633 which is more than 0.05 , meaning that the null hypothesis cannot be rejected. It also means that the error terms assumption of the normal distribution is not violated.

Table 1: Jarque-Bera test for Normality

Skewness/Kurtosis tests for Normality

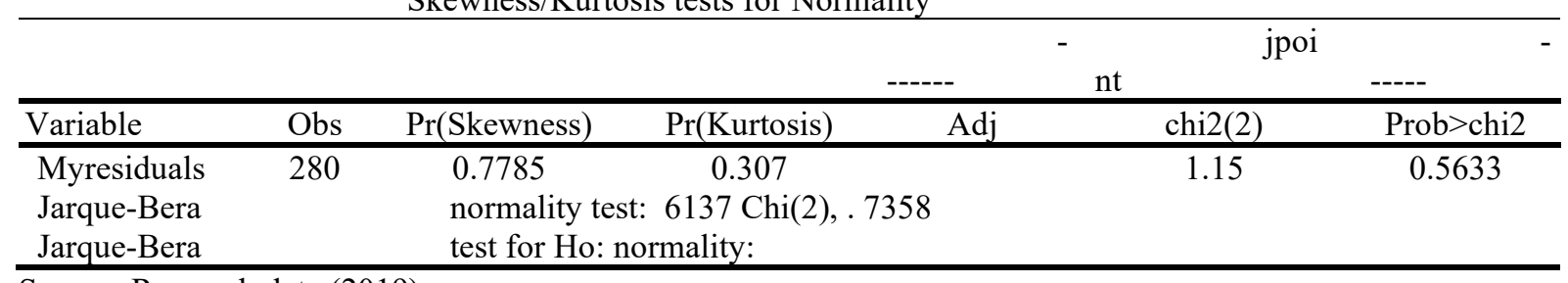

Source: Research data (2019)

Shapiro Wilk Normality test as captured in Table 2 shows that the p-value (.0514) is greater than .05 , thus the normality hypothesis cannot be rejected examined based on the premise that the residuals indicates normal distribution. 
Table 2: Shapiro-Wilk W test

\begin{tabular}{lccccc}
\hline \multicolumn{5}{c}{ Shapiro-Wilk W test for normal data } \\
\hline Variable & Obs & W & V & z & Prob $>\mathbf{z}$ \\
\hline Myresiduals & 280 & 0.96892 & 3.822 & 3.05 & 0.0514 \\
\hline
\end{tabular}

Source: Research data (2019)

The multicollinearity results of the VIF test as shown in Table 3 ranged between 1.2 and 2.04. All the variables are less than 10 thereby our model does not suffer from multicollinearity problems.

Table 3: VIF test for Multicollinearity

\begin{tabular}{rccc}
\hline Variable & & VIF & 1/VIF \\
\hline & bi & 2.04 & .490607 \\
& Acm & 1.9 & .525196 \\
fs & 1.84 & .543997 \\
bm & 1.75 & .572232 \\
bs & 1.68 & .594719 \\
aci & 1.59 & .627836 \\
& oc & 1.41 & .710181 \\
& bq & 1.33 & .754666 \\
& bd & 1.21 & .826748 \\
Mean VIF & io & 1.2 & .834352 \\
\hline
\end{tabular}

bi = board independence, $b d=$ board diversity, $b q=$ board qualifications, $b m=$ board meetings, oc $=$

ownership concentration, io = institutional ownership, aci = audit committee independence, acm = audit committee meetings, $f_{s}=$ financial strength, $b s=$ board size

Source: Research data (2019)

For the Breusch-Pagan test of the heteroskedasticity, the results indicated in the Table 4 that Chi-square (1) was .29, p-value of .5901 meaning that the null hypothesis could not be rejected, and therefore there was no violation of constant variance assumption.

Table 4 Breusch-Pagan / Cook-Weisberg Test for Heteroskedasticity

Breusch-Pagan / Cook-Weisberg test for heteroskedasticity

Ho: Constant variance

Variables: fitted values of fns

$\operatorname{chi} 2(1)=.29$

Prob $>$ chi2 $=.5901$

Source: Research data (2019)

Pearson correlation findings in Table 5 indicated that board independence is positively associated to ecological reporting with a coefficient of $\mathrm{r}=.600$. This is significant at $\mathrm{p}<.01$. Also, the results showed that board qualification is positively associated to ecological sustainability reporting through coefficient of $r=.322$, that is significant at $\mathrm{p}<.01$. In addition, the number of board meetings were also positively related to ecological sustainability reporting as shown by a coefficient of $\mathrm{r}=.377$ which is as well as significant at $\mathrm{p}<.01$.

Table 5: Pearson Correlation between Environmental Sustainability Disclosure and Corporate Governance

\begin{tabular}{|c|c|c|c|c|c|}
\hline & esd & $\mathbf{B i}$ & $\mathrm{Bq}$ & bm & fs \\
\hline Esd & 1 & & & & \\
\hline $\mathbf{B i}$ & $.600 * *$ & 1 & & & \\
\hline $\mathbf{B q}$ & $.322 * *$ & $.300 * *$ & 1 & & \\
\hline $\mathrm{Bm}$ & $.377 * *$ & $.410 * *$ & $.402 * *$ & 1 & \\
\hline Fs & $.445^{* *}$ & $.592 * *$ & $.321 * *$ & $.369 * *$ & 1 \\
\hline
\end{tabular}

Note: ** Correlation is significant at the .01 level (2-tailed). * Correlation is significant at the .05 level (2-tailed). $\mathrm{N}=56$; Dependent variable, esd $=$ Environmental sustainability disclosure, $b i=$ board independence, $b q=b o a r d$ qualifications, $\mathrm{bm}=$ board meetings, $f_{s}=$ financial strength

The results on the moderating effect of financial strength on the relationship between board characteristics and environmental sustainability disclosure can be seen from the Table 6 that there is a positive and significant moderating effect of financial strength on the relationship between board independence and environmental sustainability disclosure $(\beta=.23, \rho<.05)$. With financial strength, the effect of board independence on environmental disclosure is increased. In addition, there is a positive and insignificant moderating effect of 
financial strength on the relationship between board qualification and environmental sustainability disclosure $(\beta$ $=.13, \rho>.05)$. Finally, there is a negative and significant moderating effect of financial strength on the relationship between board meetings and environmental sustainability disclosure $(\beta=-.16, \rho<.05)$, implying that the presence of financial strength weakens the relationship between board meetings and environmental sustainability disclosure.

As such, financial strength has no impact on the relationship between board qualification and environmental sustainability disclosure. For the model $2, R^{2}=0.42$. This $R^{2}$ means that $42 \%$ of the variance in environmental sustainability disclosure is explained by board characteristics and financial strength. Model 7 indicates the results after the interaction term (board characteristics*financial strength) was included in the equation. The inclusion of the interaction term resulted in an $R^{2}$ change of 0.03 . The results show a significant presence of moderating effect. The moderating effect of financial strength explains $3 \%$ variance in environmental sustainability disclosure above and beyond the variance by board characteristics and financial strength. Thus, the null hypothesis was rejected and therefore financial strength enhances the relationship between environmental sustainability disclosure and board characteristics

Table 6: Moderation effect of Financial Strength on the relationship between Board Characteristics and Environmental Sustainability Disclosure

\begin{tabular}{|c|c|c|c|c|c|c|}
\hline Zesd & $\begin{array}{l}\text { Model } 1 \\
\text { Coef. } \\
\text { (Std.err. }\end{array}$ & $\begin{array}{c}\text { Model } 2 \\
\text { Coef. } \\
\text { (Std.err. }\end{array}$ & $\begin{array}{l}\text { Model } 3 \\
\text { Coef. } \\
\text { (Std.err. }\end{array}$ & $\begin{array}{c}\text { Model } 4 \\
\text { Coef. } \\
\text { (Std.err. }\end{array}$ & $\begin{array}{l}\text { Model } 6 \\
\text { Coef. } \\
\text { (Std.err. }\end{array}$ & $\begin{array}{c}\text { Model } 7 \\
\text { Coef. } \\
\text { (Std.err. }\end{array}$ \\
\hline cons & $.28(.04)^{* *}$ & $.17(.03)^{* *}$ & $.01(.00)^{*}$ & $.44(.00)^{* *}$ & $(-.00)(.05)$ & $(-.01(.05)$ \\
\hline$\overline{\mathrm{Z}} \mathrm{bs}$ (control) & $.02(.00)^{* *}$ & $.01(.00)^{*}$ & $.15(.03)^{* *}$ & $.00(.00)$ & $(-.03)(.06)$ & $(-.03(.06)$ \\
\hline Zbi & & $.28(.03)^{* *}$ & $.01(.00)$ & $(-.23)(.11)^{*}$ & $.41(.06)^{* *}$ & $.42(.06)^{* *}$ \\
\hline $\mathrm{Zbq}$ & & $.07(.03)^{*}$ & $(-.17)(.04)^{* *}$ & $.08(.03)^{*}$ & $.14(.05)^{*}$ & $.14(.05)^{*}$ \\
\hline $\mathrm{Zbm}$ & & $.01(.00)^{*}$ & $.07(.03)^{*}$ & $.01(.00)$ & $.14(.05)^{*}$ & $.14(.05)^{*}$ \\
\hline$Z \mathrm{fs}$ & & & $.01(.00)^{*}$ & $-.03)(.01)^{*}$ & $.09(.06)$ & $.07(.06)$ \\
\hline zbi_fs & & & & $.23(.05)^{* *}$ & $.03(.05)$ & $.09(.05)$ \\
\hline zbq_fs & & & & & $.13(.05)$ & $.15(.05)^{*}$ \\
\hline zbm_fs & & & & & & $(-.16)(.06)^{*}$ \\
\hline \multicolumn{7}{|l|}{ R-sq: } \\
\hline Within & .09 & .57 & .58 & .43 & .44 & .44 \\
\hline Between & .07 & .33 & .34 & .45 & .48 & .56 \\
\hline Overall & .07 & .42 & .43 & .44 & .45 & .47 \\
\hline$R-s q \Delta$ & .07 & .35 & .01 & .01 & .01 & .02 \\
\hline Waldchi2(9) & 12.82 & 155.91 & 148.05 & 196.19 & 213.34 & 226.65 \\
\hline Prob $>$ chi 2 & .00 & .00 & .00 & .00 & .00 & .00 \\
\hline Sigma_u & .10 & .09 & .08 & .08 & .20 & .14 \\
\hline sigma_e & .09 & .06 & .06 & .06 & .72 & .73 \\
\hline Rho & .54 & .64 & .64 & .65 & .07 & .04 \\
\hline
\end{tabular}

$b s=$ board size, $b i=$ board independence, $b q=$ board qualifications, $b m=$ board meetings, $f_{s}=$ financial strength

$* * \mathrm{p}<.01, * \mathrm{p}<.05$

Source: Research data (2019) 


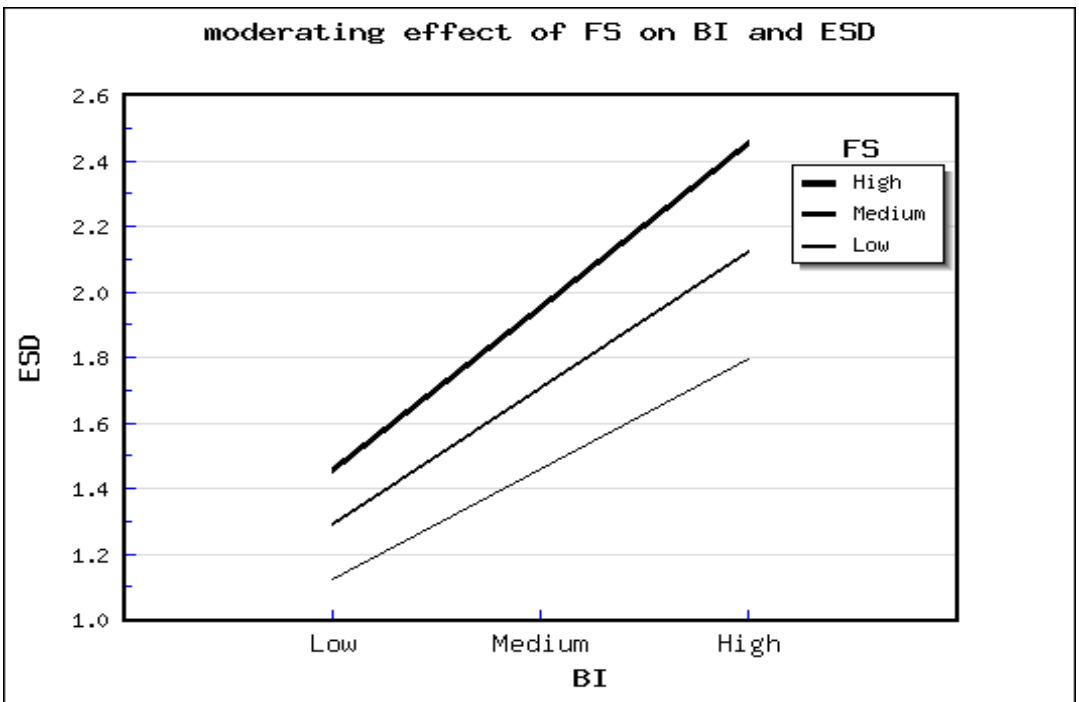

Figure 2: Modgraph for Moderating Effect of Financial Strength on Board Independence and Environmental Sustainability Disclosure

Source: Research data (2019)

To show enhancing, buffering and diminishing moderating effect, the study used modgraph as recommended by Barone, Ranamagar and Solomon (2013). Fig. 4.1 indicate enhancing moderating effect, thus at high levels of financial strength, environmental sustainable disclosure increases with increase of board independence than in medium and low levels of board independence. Further, the figure demonstrates a stronger relationship between environmental sustainable disclosure and financial strength as result of steep slope. This shows that firms with high financial strength are likely to experience increases in environmental sustainability disclosures as a result of increase in board independence (number of non-executive members). Also, it may be associated with the fact that big firms in terms of asset base have more and diverse institutional resources to implement corporate governance systems necessary for enhanced environmental disclosure as compared to small firms that may not have variety in its institutional resources.

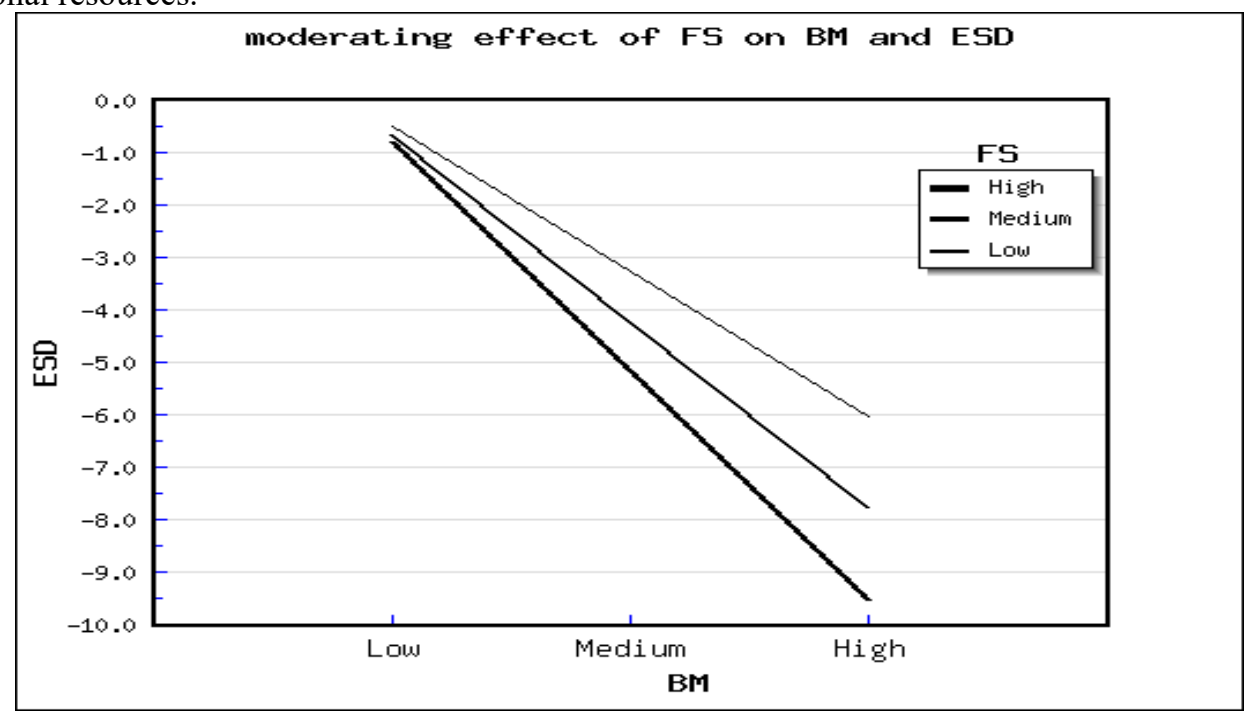

Figure 3: Modgraph for Moderating Effect of Financial Strength on Board Meetings and Environmental Sustainability Disclosure

Source: Research data (2019)

Fig. 4.3 reveals a decreasing moderating effect, thus at high levels of financial strength, environmental sustainability disclosure decreases with increase of board meetings than in medium and low levels of financial strength. Further, the figure demonstrates a stronger relationship between environmental sustainability disclosure and financial strength. This is evidenced by the slope regressing environmental sustainability disclosure on board meetings which is steeper for the large companies as compared to small companies. The results hows that firms with high financial strength are likely to experience decrease in environmental sustainability disclosure as results of decrease in the number of meetings a board holds in a year. 


\subsubsection{Discussion of Results}

Regarding the board independence, the results are in agreement with the stakeholders' theory which buttresses the need for having non-whole time service directors in the board in order to protect the investors' interest (Arayssi, Dah, and Jizi, 2016). In support of this view as well is a meta-analysis approach adopted by García- Sánchez, Frías-Aceituno and Rodríguez-Domínguez (2013) that documented that a positive and significant relationship between BI and ESD "only occurs in those countries having investor protection rights". Further, the theory is emphasized by Post, Rahman, and McQuillen (2014) that a higher degree of non-whole time service directors being on the board is expected to associate to extensive ecological effect reporting significantly.

For Ofoegbu, Odoemelam and Okafor (2018) study in Nigeria and South Africa, the board independence was statistically significant for the Nigeria sample (applying traditional reporting framework) but not significant for the South Africa sample (applying Integrated Reporting). For the Nigeria findings, they were attributed to strong corporate governance arrangements that may serve as bonding strategies in weak legal environments (traditional reporting framework), a suggestion of a substitutive association between corporate governance and the regulatory framework.

It implied that the non-executive inclusive board acts as a dimension of a better-governed firm, thus ensuring the reduction of information asymmetry (Ernstberger and Grüning, 2013). This implies that South African legal and regulatory framework (IR) is strong which substituted the degree of South Africa ecological reporting while the non-executive board of directors in Nigeria listed firms compensated for the poor regulatory environment (Adegbite, 2015). In the same vein, Odoemelam and Okafor (2018) justified the stakeholder theory on the basis that in an ecology coupled with weak legal and institutions, more of whole-time service directors will ensure stakeholders protection of their interest. Contrary to the findings is by Akbas (2016), whose results found no statistically significant association between the degree of ecological reporting and board independence. This could be attributed to the use of a sample other than the entire population. In addition, the study was limited to nonfinancial firms.

On the board meetings, the frequency board activities are expected to have positive influence on the level of ecological disclosure (Beekes, Brown, Zhan and Zhang, 2016; Prasad, Mishra and Kalro, 2017). The board meetings result also contradict the argument that frequency of the board meetings enhances the quantity of environmental disclosure and will help overcome agency conflicts (Ntim and Osei, 2011). In consonance with the results was Osazuwa, Che-Ahmad and Che-Adam (2016), an indication that there was no much board activity. However, Odoemelam and Okafor (2018) results were contrary. This could be attributed to the utilization of crosssectional data unlike the current study using longitudinal data. Also, the study was limited to the annual reports in comparison to the current study that used varied secondary data sources. Further, the contrary findings could have been attributed to the exclusion of some segments such as the financial firms, as it was limited to non-financial firms only.

Generally, the moderated results though indicating varied effect (either positive or negative), were statistically significant. This is contrary to Ofoegbu and Megbuluba (2016) whose findings rejected the alternative hypothesis, thus concluding that firm financial strength does not affect the quality of Corporate Environmental Accounting Information Disclosure (CEAID) in the Nigeria manufacturing firms.

\subsubsection{Conclusions}

The study assessed the influence of board characteristics on environmental sustainability disclosure. The focus was on board independence board qualification and board meetings. With reference board independence, results have shown that having a large proportion of independent directors on the board lead the firms listed in NSE to increase their environmental sustainability disclosure. This implies that the more the firms have external directors, the more likely they may participate and influence on environmental disclosure decisions. This is due to the fact that external directors are autonomous of management as well as more effective in protecting the interests of shareholders. Also, they have an understanding of the external environment. A balanced board is therefore important for balanced board composition and enhanced environmental sustainability disclosure.

Further, board qualification was associated with an increase in environmental sustainability disclosure. The implication is that the quality of the board in terms of their professional qualification, experience and talents are vital towards enhancing environmental sustainability disclosure.

Finally, findings on board characteristics, the number of board meetings had no influence on environmental sustainability disclosure. Therefore, increase in the number of board meeting will have no influence on environmental disclosure.

\subsubsection{Recommendations and Suggestions for Further Research}

On board qualification, additional aspects with regard to having environmental management skills could be incorporated as one of the board member data collection and measuring criteria. This study focuses on NSE listed firms in Kenya. Further studies can as well examine ecological sustainability disclosure issues for small-andmedium enterprises (SMEs), as they are also facing sustainable development issues, and dealing with them in an unobservable way. Studies on SMEs can add value to the contemporaneous ecological sustainability literature 
from a new dimension.

On the data collection instruments, further studies could consider use of both the primary data and secondary data in order to supplement the available secondary data with the stakeholder's opinions about corporate ecological reporting and what more is required to ensure firms are fully environmentally compliant.

Future research can be executed on two different time periods such as before the release of some new law or guideline pertaining to environmental disclosure and after its release. For instance, some years before the release of a particular environmental disclosure law and others after, such as the release of the International Financial Reporting Standards (IFRS) on new reporting framework, Integrated Reporting (IR) with effect from the year 2014, from the traditional reporting framework. The traditional reporting framework was based on voluntary ecological disclosure while integrated reporting is premised on mandatory ecological disclosure. The results of such research will generate an idea of how environmental disclosure laws are implemented in Kenya. Additional research could be conducted in other countries (emerging or developed) using the same tested variables. This would allow a crosscountry comparison. Such additional studies would provide a cross-country comparison between an emerging market (Kenya) with that of a developed market to compare and contrast different behaviours by institutions with regard to enhancing environmental disclosure. Or, a cross-country comparison of two emerging markets to determine if similar results were generated.

\section{REFERENCES}

AbuRaya, K. R. (2012). The relationship between corporate governance and environmental disclosure: UK Evidence. (Doctoral dissertation). Durham University.

Adegbite, E. (2015). Good corporate governance in Nigeria: Antecedents, propositions, and peculiarities. International Business Review, 24(2), 319-330.

Adeniyi, S. I., \& Fadipe, A. O. (2018). Effect of board diversity on sustainability reporting in Nigeria: A study of beverage manufacturing firms. Indonesian Journal of Corporate Social Responsibility and Environmental Management, 1(1), 43-50.

Agustiningsih, W. S., Murni, S., \& Putri, A. G. (2017). Audit findings, local government characteristics, and local government financial statement disclosure. Review of Integrative Business and Economics Research, 6(3), $179-187$.

Akbas, H. E. (2016). The relationship between board characteristics and environmental disclosure: Evidence from Turkish listed companies. South East European Journal of Economics and Business, 11(2), 7-19.

Allegrini, M., \& Greco, G. (2013). Corporate boards, audit committees and voluntary disclosure: Evidence from Italian listed companies. Journal of Management \& Governance, 17(1), 187-216.

Anazonwu, H. O., Egbunike, F. C., \& Gunardi, A. (2018). Corporate board diversity and sustainability reporting: A study of selected listed manufacturing firms in Nigeria. Indonesian Journal of Sustainability Accounting and management, 2(1), 65-78.

Arayssi, M., Dah, M., \& Jizi, M. (2016). Women on boards, sustainability reporting and firm performance. Sustainability Accounting, Management and Policy Journal, 7(3), 376-401.

Bansal, P., \& Clelland, I. (2004). Talking trash: Legitimacy, impression management, and unsystematic risk in the context of the natural environment. Academy of Management Journal, 47(1), 93-103.

Bansal, P. (2005). Evolving sustainably: A longitudinal study of corporate sustainable development. Strategic Management Journal, 26, 197-218.

Barako, D. G., \& Brown, A. M. (2008). Corporate social reporting and board representation: Evidence from the Kenyan banking sector. Journal of Management \& Governance 12 (4), 309-324.

Barako, D. G., Hancock, P., \& Izan, H. Y. (2006). Factors influencing non-mandatory corporate disclosure by Kenyan companies. Corporate Governance, 14(2), 107-125.

Barone, E., Ranamagar, N., \& Solomon, J.F. (2013). A habermasian model of stakeholder (non) engagement and corporate (ir) responsibility reporting. Accounting Forum, 37(3), 163-181.

Barrett, P. (2004). Public sector reporting and triple bottom line. Speech by the auditor-general for Australia, Department of Environment and Heritage, Sustainability reporting by the public sector. Retrieved from http://www.anao.gov.au/WebSite.nsf/ accessed on 15.07.17.

Beekes, W., Brown, P., Zhan, W., \& Zhang, Q. (2016). Corporate governance, companies' disclosure practices and market transparency: A cross country study. Journal of Business Finance \& Accounting, 43(3-4), 263297.

Bhagat, S. \& Bolton, B.J. (2008). Corporate governance and firm performance. Journal of Corporate Finance, 14(3), 257-273.

Bhattacharyya, A. (2014). Factors associated with the social and environmental reporting of Australian companies. Australasian Accounting, Business and Finance Journal, 8(1), 25-5. doi:1.14453/aabfj.v8i1.3

Bokpin, A. G., Isshaq, Z., \& Nyarko, E. S. (2015). Corporate disclosure and foreign share ownership: Empirical evidence from African countries. International Journal of Law and Management, 57(5), 417-444. Retrieved 
from https://doi.org/1.1108/IJLMA-01-2014-0004

Borunda, A. (2019). The last five years were the hottest ever recorded: The planet is warming up, and there's no sign of stopping. Retrieved from https:/www.nationalgeographic.com/environment/2019/02/2018-fourthwarmest-year-ever-noaa-nasa-reports/

Campbell, D., Craven, B., \& Shrives, P. (2003). Voluntary social reporting in three FTSE sectors: A comment on perception and legitimacy. Accounting, Auditing \& Accountability Journal, 16(4), 558-581.

Chen, J. C., \& Robert, R. W. (2010). Toward a more coherent understanding of the organization-society relationship: A theoretical consideration for social \& environmental accounting research. Journal of Business Ethics, 97, 651-665. Retrieved from http://dx.doi.org/1.1007/s10551-010-0531-0

Cheruiyot, H. (2017). Implementation of the corporate governance code and the role of governance auditors. Capital Market Authority (CMA), Kenyar Retrieved from https://www.cma.or.ke/index.php/regulatoryframework/corporate-governance-for-issuers

Cho, C., \& Patten, D. (2007). The role environmental disclosures as tools of legitimacy: A research note. Accounting, Organizations and Society, 32(7/8), 639-647.

Climate Central (2019). The 10 Hottest Global Years on Record. Retrieved from https://www.climatecentral.org/gallery/graphics/the-10-hottest-global-years-on-record

Cormier, D., \& Gordon, I. M. (2001). An examination of social and environmental reporting strategies. Accounting, Auditing \& Accountability Journal, 14 (5), 587-617.

Debreceny, R., Gray, G., \& Rahman, I. (2002). The determinants of internet financial reporting. Journal of Accounting and Public Policy, 21(4-5), 371-394.

Deegan, C. (2002). Introduction: The legitimizing effect of social and environmental disclosures - a theoretical foundation. Accounting, Auditing and Accountability Journal, 15(3), 282-311.

Dibia, O. N., \& Onwuchekwa, C. J. (2015). Determinants of environmental disclosures in Nigeria: A case study of oil and gas companies. International Journal of Finance and Accounting, 4 (3), 145-152. DOI: $1.5923 /$ j.ijfa.20150403.01

Echave, O. J., \& Bhati, S. S. (2010). Determinants of social and environmental disclosures by Spanish companies. GSMI Third End year International Business Conference (pp. 55-68). USA: Global Strategic Management Inc..

Elkington, J. (1997). Cannibals with forks: The triple bottom line of 21 st century business. capstone.

Ernstberger, J., \& Grüning, M. (2013). How do firm- and country-level governance mechanisms affect firms' disclosure? Journal of Accounting and Public Policy, 32(3), 50-67.

Ettredge, M. (2011). The effects of company size, corporate governance quality, and bad news on disclosure compliance. Review of Accounting Studies. Retrieved from http://kuscholarworks.ku.edu/dspace/.

Farneti, F. \& Guthrie, J. (2009). Sustainability reporting by Australian public sector organizations: Why they report? Accounting Forum, 33(2), 89-98.

García-Sánchez, I., Frías-Aceituno, J.V., and Rodríguez-Domínguez, L. (2013). Determinants of corporate social disclosure in Spanish local governments. Journal of Cleaner Production, 39, 60-72.

Gallego-Álvarez, I., Rodríguez-Domínguez, L., \& García-Sánchez, I. (2010). Are determining factors of municipal e-government common to a worldwide municipal view? An intra-country comparison. Government Information Quarterly, 27(4), 423-43.

González, E., Cárcaba, A., Ventura, J., \& García, J. (2011). Measuring quality of life in Spanish municipalities. Local Government Studies, 37(2), 171-197.

Gray, R., \& Milne, M. J., (2002). Sustainability reporting: Who's kidding whom? Centre for Social and Environmental Accounting Research. (Accountability, Transparency, Sustainability, no. 1, pp. 1-5).

Greiling, D., \& Grüb, B. (2014). Sustainability reporting in Austrian and German local public enterprises. Journal of Economic Policy Reform, 17(3), 209-223. Doi: 1.1080/1748787.2014.909315. Retrieved from http://dx.doi.org/1.1080/1748787.2014.909315

Grüning, M., \& Ernstberger, J. (2010). The association between disclosure and corporate governance. Working Paper, European University Viadrina Frankfurt (Oder) and Ruhr-University Bochum.

Gul, F. A., \& Leung, S. (2004). Board leadership, outside directors' expertise and non-mandatory corporate disclosures. Journal of Accounting and Public Policy, 23(5), 351-379.

Habbash, M. (2016). Corporate governance and corporate social responsibility disclosure: Evidence from Saudi Arabia. Social Responsibility Journal, 12(4), 740-754.

Hossain, M., \& Reaz, M. (2007). The determinants and characteristics of voluntary disclosure by Indian banking companies. Corporate Social Responsibility and Environmental Management, 14(5), 274-288.

ICPAK (2017). Status update on IFRSs, IPSASs and IR in Kenya. Retrieved from https://www.icpak.com/wpcontent/uploads/2017/11/Status-update-on-IFRSs-IPSASs-and-IR-in-Kenya.pdf.

Ienciu, I.-A., Popa, I. E., \& Ienciu, N. M. (2012). environmental Reporting and Good Practice of Corporate Governance: Petroleum industry case study. Procedia Economics and Finance, 3, 961-967. 
Integrated Reporting (2017). Breakthrough: IIRC integrated report. Retrieved from https://integratedreporting.org/integratedreport2017/download/pdf/IIRC_INTEGRATED_REPORT_2017.p df

Jensen, M. C., \& Meckling,W. H. (1976). Theory of the firm: Managerial behavior, agency costs and ownership structure. Journal of Financial Economics, 3(4), 305-360.

Jizi, M. (2017). The influence of board composition on sustainable development disclosure. Business Strategy and the Environment, 26(5), 640-655.

Kabir, R., \& Thai, H. M. (2017). Does corporate governance shape the relationship between corporate social responsibility and financial performance? Pacific Accounting Review, 29(2), 227-258.

Karim, K. E., \& Rutledge, R.W. (2004). Environmental disclosure practices and financial performance. Westport, London: Greenwood Publishing Group.

Kathyayini. K. R., Carol, A. T., \& Laurence, H. L. (2012). Corporate governance and environmental reporting: An Australian study. Corporate Governance: The international journal of business in society, 12(2), 143-163. Retrieved from https://doi.org/1.1108/14720701211214052

Khodadadi, V., Khazami, S., \& Aflatooni, A. (2010). The effect of corporate governance structure on the extent of voluntary disclosure in Iran. Business Intelligence Journal, 151-164.

Larrinaga-Gonzalez, C., \& Bebbington, J. (2001). Accounting change or institutional appropriation? - A case study of the implementation of environmental accounting. Critical Perspectives on Accounting, 12, $269-292$.

Liao, L., Luo, L. \& Tang, Q. (2014). Gender diversity, board independence, environmental committee and greenhouse gas disclosure. The British Accounting Review, 47 (4), 409-424.

Lim, S., Matolcsy, Z. \& Chow, D. (2007). The association between board composition and different types of voluntary disclosure. European Accounting Review, 16(3), 555-583.

Lodhia, S. (2010). Sustainability Reporting by the Australian Commonwealth Public Sector.

Mahadeo, J. D., Oogarah-Hanuman, V., and Soobaroyen, T. (2011). Changes in social and environmental reporting practices in an emerging economy (2004-2007): Exploring the relevance of stakeholder and legitimacy theories. In Accounting Forum, 35 (3), 58-175.

Mahmood, M., \& Orazalin, N. (2017). Green governance and sustainability reporting in Kazakhstan's oil, gas, and mining sector: Evidence from a former USSR emerging economy. Journal of Cleaner Production, 164, 389397. Retrieved from www.elsevier.com/ locate/jclepro

Martani, D., \& Liestiani, D. A. (2010). Disclosure in local government financial statements: the case of Indonesia. End year Meeting and Conference Asian Academic Accounting Association (AAAA).

McFie, J. (2018). Integrated reporting must be the result of integrated thinking: The King IV report on corporate governance. The Accountant. Journal of the Institute of Certified Public Accountant of Kenya. 4-7.

Musyoka, M. N. (2017). Effect of voluntary disclosure on financial performance of firms listed at Nairobi Securities Exchange. (Masters dissertation). School of Business and Public Management, KCA University.

Mutiva, J. M. (2016). The relationship between voluntary disclosure and financial performance of selected companies quoted at the Nairobi Securities Exchange. (Masters dissertation). School of Business, Technical University of Mombasa.

Nairobi Securities Exchange (2013). NSE Handbook (2017-2018). Nairobi, Kenya.

Naser, K., Al-Hussaini, A., Al-Kwari, D., \& Nuseibeh, R. (2006). Determinants of corporate social disclosures in developing countries: The case of Qatar. Advances in International Accounting, 19, 1-23.

Navarro, A. G., Berjillos, A. R., Lozano, M. R., \& Valencia P. T. (2015). Identifying Motivation of the Local Governments to Improve the Sustainability Transparency. Transylvanian Review of Administrative Sciences, $45,149-167$.

Ngatia, C. N. (2014). Exploring sustainability reporting for financial performance of selected companies listed at the Nairobi Securities Exchange in Kenya. International Academic Journal of Economics and Finance, 1 (4), $32-48$.

Niemann, L., \& Hoppe, T. (2017). Sustainability reporting by local governments: A magic tool? Lessons on use and usefulness from European pioneers. Public Management Review. doi: 1.1080/14719037.2017.1293149

Ntim, C. G., \& Osei, K. A. (2011). The impact of corporate board meetings on corporate performance in South Africa. African Review of Economics and Finance, 2(2), 83-103.

Obigbemi, I. F., Iyoha F. O., \& Ojeka S., A. (2015). Firm size and financial performance: A determinant of corporate governance disclosure practices of Nigerian companies. Journal of Accounting and Auditing: Research \& Practice, 2015, DOI: 1.5171/2015.467294

Odoemelam, N., \& Okafor, R. G. (2018). The influence of corporate governance on environmental disclosure of listed non-financial firms in Nigeria. Indonesian Journal of Sustainability Accounting and Management, 2(1), 25-49.

O’Dwyer, B. (2003). Conceptions of corporate social responsibility: The nature of managerial capture. Accounting, Auditing and Accountability Journal, 16(4), 523-557. 
Ofoegbu, G. N., \& Megbuluba, A. (2016). Corporate environmental accounting information disclosure in the Nigeria manufacturing firms. International Journal of Management Sciences and Business Research, 5 (12), 208-220. Retrieved on 15/12/2018 from http://www.ijmsbr.com.

Ofoegbu, G. N., Odoemelam, N., \& Okafor, R. G. (2018). Corporate board characteristics and environmental disclosure quantity: Evidence from South Africa (integrated reporting) and Nigeria (traditional reporting).Cogent Business \& Management, 5, 1-27. Retrieved on 15/12/2018 from https://www.researchgate.net/publication/329424160.

Ong, T., \& Djajadikerta, H. G. (2017). Impact of corporate governance on sustainability reporting: Empirical study in the Australian Resources Industry. In 8th Conference on Financial Markets and Corporate Governance.

Onuorah, O. A., Egbunike, F. C., \& Gunardi, A. (2018). The influence of corporate board attributes on voluntary social disclosure of selected quoted manufacturing firms in Nigeria. Indonesian Journal of Applied Business and Economic Research, 1(1), 20-33.

Osazuwa, N. P., Che-Ahmad, A., \& Che-Adam, N. (2016). Board characteristics and environmental disclosure in Nigeria. Information (Japan), 19(18A), 3069-3074.

Owen, D., Swift, T., Humphrey, C., \& Bowerman, M. (2000). The new social audits: Accountability, managerial capture or the agenda of social champions? The European Accounting Review, 9(1), 81-98.

Post, C., Rahman, N., \& McQuillen, C. (2014). From board composition to corporate environmental performance through sustainability-themed alliances. Journal of Business Ethics, 130(2), 423-435.

Post, C., Rahman, N., \& Rubow, E. (2011). Green governance: Boards of directors' composition and environmental corporate social responsibility. Business and Society, 50(1): 189-223.

Prado-Lorenzo, J., Gallego-Alvarez, I., Garcia- Sanchez, I., \& Rodriguez-Dominguez, L. (2009). Social responsibility in Spain: Practices and motivation in firms. Management Decisions, 46, 1247-1271.

Prasad, M., Mishra, T., \& Kalro, A. D. (2017). Environmental disclosure by Indian companies: An empirical study. Environment, Development and Sustainability, 19(5), 1999-2022.

Qingliang, T., \& Luo, L. (2016) Corporate ecological transparency: Theories and empirical evidence. Asian Review of Accounting, 24(4), 498-524.

Rao, K., \& Tilt, C. (2016b). Board Diversity and CSR Reporting: An Australian Study. Meditari Accountancy Research, 24(2), 182-210.

Reverte, C. (2009). Determinants of corporate social responsibility disclosures ratings by Spanish listed firms. Journal of Business Ethics, 88(2), 351-366.

Rockness, J.W. (1985). An Assessment of the relationship between US corporate environmental performance and disclosure. Journal of Business Finance \& Accounting, 339-354.

Said, R., Zainuddin, Y. H., \& Haron, H. (2009). The relationship between corporate social responsibility disclosure and corporate governance characteristics in Malaysian public listed companies. Social Responsibility Journal, $5(2), 212-226$.

Saunders, M. (2016). Understanding research philosophies and approaches. University of Birmingham

Sharif, M., \& Rashid, K. (2014). Corporate governance and corporate social responsibility (CSR) reporting: An empirical evidence from commercial banks (CB) of Pakistan. Quality \& Quantity 48(5), 2501-2521.

Simpson, S. N. Y. (2013). Public sector reform and disclosure practices of state-owned enterprises: The case of Ghana. (Doctoral dissertation). Department of Accounting and Finance, Business School, University of Birmingham.

Swastika, T. L. D. (2013). Corporate governance, firm size, and earning management: evidence in Indonesia stock exchange. Journal of Business and Management, 10(4), 77-82.

Tagesson, T., Klugman, M., \& Ekstrom, M. L. (2013). What explains the extent and content of social disclosures in Swedish municipalities' end year reports. Journal of Management and Governance, 17, 217-235.

Williams, C. C. (2008). Toward a taxonomy of corporate reporting strategies. Journal of Business Communication, 45(3), 232-264.

Zahra, S.A. and Pearce II, J.A. (1989). Board of directors and corporate financial performance: A review and integrative model. Journal of Management, 15(2): 291-334. 